\title{
Populismi ei ole vain populismia
}

Populismi ja varsinkin uusoikeistolainen populismi moninaisissa muodoissaan fasistisesta ja natsistisesta äärioikeistosta uuskonservatiiveihin on noussut merkittäväksi tutkimuskohteeksi myös politiikan tutkimuksessa. Huolestuttavaa olisikin, jos populismia ei oppialallamme laajasti tutkittaisi. Toinen kysymys on se, millaisia rajoituksia ja rajoitteita erityistieteiden väliset akateemiset rajanvedot ja työnjaot muodostavat populistisen politiikan tai politiikan populistisuuden analyysille. Palaan tähän kysymykseen kirjoitukseni lopussa. Sitä ennen esitän seitsemän teesiä, joiden konkreettinen fokus on nykyisessä uusoikeistolaisessa populismissa ja eräissä sen historiallisissa lähtökohdissa.

\section{SEITSEMÄN TEESIÄ POPULISMISTA}

1. "Kansaan" vetoava ja "kansalla" argumentoiva uusoikeistolainen populismi ei ole populaaria politiikkaa. Jälkimmäisessä on kysymys sellaisista "alhaalta päin" nousevista poliittisista liikkeistä, jotka pyrkivät purkamaan olemassa olevia eriarvoisia yhteiskunnallisia suhteita ylläpitäviä hierarkkisia rakenteita ja käytäntöjä sekä myös korvaamaan ne demokraattisemmilla rakenteilla ja käytännöillä. Historiallisessa katsannossa tällaisia "populaaristi kansallisia" mutta kansakuntien rajat ylittävästi vaikutusvaltaisia liikkeitä ovat olleet muun muassa Ranskan vallankumousten 1789 ja 1848 radikaali porvarillinen jakobinismi sekä 1800-luvun loppupuolelta alkaen joukkopuolueiksi organisoitunut työväenliike. Radikaaleimmillaan jälkimmäinen ulotti demokratian vaatimuksensa myös kapitalistisiin tuotantosuhteisiin ja reformistisissa muodoissaan pyrki rakentamaan tulo- ja varallisuuseroja tasoittavaa sekä väestön enemmistön toimintakykyä kasvattavaa hyvinvointivaltiota.

Sen sijaan uusoikeistolaisessa populismissa "kansaan" vetoava ja "kansalla" argumentoiva retoriikka liittyy autoritaarisiin poliittisiin pyrkimyksiin. Niissä ei ole kysymys laajojen väestönosien kasvavasti itseorganisoituvasta poliittis-yhteiskunnallisesta toiminnasta yhteiskunnan muuttamiseksi, vaan kuvitellulle "kansalle" ylhäältä päin suunnatuista autoritaarisista hankkeista. Demokraattisten pyrkimysten sijasta uusoikeistolaiset populistit esittävät vahvaan johtajuuteen ja hierarkkiseen järjestelmään perustuvia ratkaisuja määrittelemiinsä yhteiskunnallisiin ongelmiin. Autoritaarisuus näkyy myös luonnollisina esitettyinä hierarkioina muun muassa etnisten ryhmien, kansakuntien, "rotujen", uskontokuntien ja myös sukupuolten välillä.

2. Demokratian ongelmat ovat avanneet portit uusoikeistolaiselle populismille. Uusoikeistolaisen populismin nousu liittyy demokratian ongelmiin ja sen kaventumiseen liberaalidemokratiaksi. Populaaristi kansallisten demokraattisten hankkeiden tyrehtyminen ja perinteisten puolueiden etääntyminen äänestäjäkunnasta ja monen väestöryhmän jokapäiväisestä elämästä ovat avanneet portit "unohdettuun" tai kaltoin kohdeltuun "kansaan" vetoaville uusoikeistolaisille populistisille pyrkimyksille. Autoritaarinen uusoikeistolainen populismi on demokratian kriisin kääntöpuoli. 
3. Demokratian ongelmat liittyvät kapitalismin ongelmien ja kriisien uusliberalistisiin ratkaisuihin. Kapitalismin uusliberalistinen käänne ei ole ollut vain maailmantaloutta ja kansainvälisiä suhteita muuttanut vapaakauppaideologia, vaan myös reaktio aikansa eläneiksi, liian kalliiksi ja "tervettä" kilpailua rajoittaviksi katsottuja läntisiä hyvinvointivaltioita vastaan. Uusliberalismissa hyvinvointivaltioiden "rahoitusongelmia" ei määritelty kapitalismista vaan itse hyvinvointivaltiosta johtuvaksi ongelmaksi. Ratkaisuksi omaksuttiin muun muassa julkisten palveluiden yksityistäminen, markkinavoimien vapauttaminen, kilpailu ja kilpailuttaminen, "vastikkeettomien" tukien ja universaalien palveluiden purkaminen sekä koulutuksen alistaminen työ- ja elinkeinoelämän vaatimuksille.

Näitä uusliberalistisia ajattelutapoja omaksuttiin ja otettiin käyttöön myös keskeisissä hyvinvointivaltion rakentajapuolueissa, kuten Suomessa SDP:ssä ja Keskustassa. Kansainvälisesti tunnetuin esimerkki on Tony Blairin vuosina 1997-2007 johtama Britannian työväenpuolue, joka hallitusvallassa olleessaan toteutti monessa suhteessa uusliberalistista politiikkaa. 2000-luvulla uusliberalismista on tullut poliittisten eliittien keskuudessa vallitsevaa "tervettä järkeä" siinä määrin, ettei poliittisten ratkaisujen uusliberalistisia piirteitä aina edes tunnisteta.

4. Populismi ei rajoitu uusoikeistoon. Demokratian kaventuminen ja puolueiden "kansayhteyden" rajoittuminen lähinnä vaalikampanjoihin ja yhteiskunnallisten suhteiden organisoimiseen ylhäältä päin hallitusvaltaa käyttämällä ruokkivat populistisia vaalistrategioita. Perinteiset oikeisto-, keskusta- ja vasemmistopuolueet ovat pyrkineet vastaamaan uusoikeistolaiseen populismiin myös sen omilla aseilla eli populistisia piirteitä sisältävillä vaaliohjelmilla. Puolueiden etääntyminen laajojen väestöryhmien elämästä tuottaa tilanteen, jossa yhteyttä kansalaisiin pyritään pitämään yllä, varsinkin vaalien alla, populistisen mediapolitiikan keinoin. Muut puolueet ovat myös omaksuneet oikeistopopulistista agendaa omiin ohjelmiinsa. Esimerkistä käy "maahanmuuttokriittisyyden" voimistuminen muissakin kuin uusoikeistolaisissa puolueissa.

Populismista on puhuttu myös eräiden nykyisten vasemmistopuolueiden, kuten Espanjan Podemosin ja Kreikan Syrizan, yhteydessä tai viimeksi Bernie Sandersin presidentinvaalikampanjaan viitaten Yhdysvalloissa. Myös Ernesto Laclaun esityksissä vasemmistopopulismi on näkyvässä roolissa, mihin yhtenä tekijänä on ollut vaikuttamassa hänen omakohtaiset kokemuksensa peronismista synnyinmaassaan Argentiinassa. Vasemmistopopulistisiksi määriteltyjen puolueiden ja poliittisten liikkeiden tapauksissa on kuitenkin syytä kysyä, ovatko ne laajojen väestöryhmien aktivoitumiseen perustuvia, olemassa olevia hierarkkisia käytäntöjä ja elitistisiä rakenteita purkamaan pyrkiviä populaareja liikkeitä vai eivät. Mikäli ne ovat sellaisia, silloin niiden populistiset piirteet on hahmotettava yhteyksissään koko yhteiskuntamuodostuman radikaalin muuttamisen pyrkimyksiin. Niissä on kysymys alistetussa asemassa olleiden väestönosien ("subalterns") poliittis-yhteiskunnallisesta aktivoitumisesta, eikä vain sen nimissä esitetyistä populistisista väitteistä "eliittien vallasta" tai "kansan unohtamisesta".

Tällaisten myös "alhaalta päin" organisoituvien vastahegemonisten liikkeiden tapauksessa olisi kohdallisempaa puhua vasemmistopopulismin sijasta populaarista vasemmistolaisuudesta, johon voi sisältyä myös "populistisia" piirteitä. Tällöin populismi kuitenkin niveltyy osaksi populaaria liikettä, eikä populismi ole silloin tartuntavoimaisin teoreettinen käsite tällaisen liikkeen luonteen ymmärtämiseksi. Onkin syytä tehdä ero populaarin ja populistisen välillä unohtamatta kuitenkaan niiden välisiä tosiasiallisia vaihtelevia yhteyksiä. 
5. Uusoikeistolainen populismi ei ole välttämättä uusliberalismin vastaista politiikkaa. Vaikka monessa maassa perinteiset puolueet ovat määritelleet uusoikeiston vastustajakseen ja toisaalta uusoikeisto on arvostellut äänekkäästi perinteisiä puolueita, ei rintamalinjoja tule pitää pysyvinä tai kovia puheita koko totuutena, vaan kiinnittää huomiota myös yhdistäviin tekijöihin ja rajat ylittäviin liittoutumispyrkimyksiin. Uusoikeistossa onkin omaksuttu myös uusliberalistisia näkemyksiä ja tehty kädenojennuksia uusliberalistien suuntaan, kuten Perussuomalaiset jo Sipilän hallituksessa tai viime eduskuntavaalien jälkeen. Tämän muutoksen tunnistaminen EU-eliittiin kohdistetun kritiikin ja vuolaan kansaretoriikan seasta ei ole osoittautunut helpoksi tehtäväksi varsinkaan valtamediassa, semminkin kun uusliberalismista on tullut osa myös valtamedian "tervettä järkeä". Uusliberalismin näkökulmasta katsoen uusoikeistolaisen populismin autoritaarinen luonne ei välttämättä ole ylittämätön ongelma, sillä eihän populaaridemokraattinen antiautoritaarinen pyrkimys sosiaaliseen tasavertaisuuteen tai tuloerojen tasaamiseen ole uusliberalistisessa ideologiassa mitenkään myönteisenä näyttäytyvä asia, vaan ennemminkin vapaata markkinataloutta uhkaava tekijä.

Sekä uusoikeiston että uusliberaalien onkin "yllättävän" helppo olla yhtä mieltä esimerkiksi siitä, että turvapaikanhakijat tulevat liian kalliiksi mutta työperäinen maahanmuutto on kansantalouden kannalta myönteinen asia. Tässä uusliberalismi tekee irtioton perinteisestä toleraation liberaalista periaatteesta, kun taas autoritaariset näkemykset ja menettelytavat valtaavat alaa.

6. Uusoikeistolainen populismi ei ole täysin uusi asia. Nykyisen uusoikeistolaisen populistisen politiikan piirteitä on löydettävissä jo aiemmista historian vaiheista. Keskeisen eurooppalaisen esimerkin tarjoaa italialainen fasismi. Fasistisessa liikkeessä vedottiin popoloon, jonka ulkopuolelle kuitenkin suljettiin muun muassa työväenliikkeeseen tai muihin fasistisen terrorin kohteeksi otettuihin poliittisiin ryhmittymiin kuuluneet väestönosat. Fasistien valtaannousun (vuonna 1922) kannalta keskeistä oli, että pohjoisen kapitalistien ja etelän suurtilallisten silmissä fasismi oli yhteiskunnallinen voima, joka pystyi torjumaan radikalisoituneen työväenluokan ja sen liittolaisten "uhkaavat" pyrkimykset sekä myös nostamaan maan ensimmäisen maailmansodan jälkeisestä talouskriisistä ja luomaan vahvan valtiomahdin heikoksi osoittautuneen liberaalidemokratian tilalle. Fasistit vetosivat myös niihin väestön keskiryhmiin, jotka katsoivat olevansa heikoilla sodanjälkeisessä tilanteessa. Valtaan noustuaan fasismi osoittautui järjestelmäksi, joka ei suinkaan uhannut kapitalismin voitonjaon periaatteita, vaan pyrki korporatiivisin keinoin ja ammattiyhdistysliikkeen valtaansa alistamalla parantamaan Italian asemaa kansainvälisessä kilpailussa vahvempia kapitalistisia valtioita vastaan. ${ }^{1}$

7. Uusoikeistolainen populismi on moniulotteinen, ristiriitainen ja muuttuva ilmiö. Tämä ei johdu vain populististen puolueiden tai muiden ryhmittymien sisäisistä ja niiden välisistä ideologisista eroista, vaan myös muuttuvista suhteista ja suhtautumisista muihin poliittisiin ja yhteiskunnallisiin toimijoihin puolueista elinkeinoelämän organisaatioihin. Jäykkien oikeisto-keskusta-vasemmisto-jakojen tai oletettujen ideologisten peruserojen sijasta onkin syytä tutkia sitä, miten eri poliittiset puolueet ja ryhmittyvät tosiasiallisesti muodostavat keskinäisiä liittoutumia, millaisten "ydinongelmien" ympärille ne kokoontuvat ja miten niissä määritellään yhteiset vastustajat ja poliittiset tavoitteet. 
Esimerkiksi Perussuomalaisten eduskuntavaaliohjelmassa 2007 asetuttiin hyvinvointivaltion universaalisuuden ja sosiaalisen oikeudenmukaisuuden periaatteiden kannalle, mutta toisaalta ne rajattiin koskemaan yksinomaan Suomen kansalaisia. Sipilän hallituksessa ja sen jälkeen Halla-ahon valtakaudella on kuitenkin tapahtunut tosiasiallinen ja myös aatteellinen siirtymä uusliberalismin suuntaan. "Uusoikeistolle" ei olekaan järkevää yrittää esittää pysyväksi tarkoitettuja "olemusmääritelmiä", vaan sellaisten sijaan tutkia sitä vaihtelevasti artikuloiduissa ideologis-poliittisissa yhteyksissään niin uusliberalismiin kuin toisaalta perinteiseen oikeistokonservatismiin tai myös keskusta- ja vasemmistopuolueisiin.

Edellisten teesien tarkoituksena on tuoda esille sitä, että uusoikeistolaista populismia tulisi tarkastella artikulaatioiden politiikkana. Se ei rajoitu vain politiikaksi kutsutulle sektorille tai hallitusneuvotteluihin, vaan siinä on kysymys "poliittisen" niveltämisestä "taloudelliseen" ja "kulttuuriseen". Artikulaatiot eivät rajoitu poliittisiin liittoutumiin. Esimerkiksi turvapaikanhakijoihin kielteisesti suhtautuva maahanmuuttopolitiikka on sekä poliittista (kuten turvapaikkakiintiöiden pienentäminen), taloudellista (kuten kansantaloudellisten kustannusten arvosteleminen) että kulttuurista (kuten rasismi ja ksenofobinen nationalismi) yhteiskuntamuodostuman artikulaatiota.

Politiikassa ei ole pysyviä asemia tai valmiita kollektiivisia toimijoita kiveen hakattuine ideologioineen. Siinä ei ole mitään takuuvarmaa, eikä myöskään mitään täysin omalakista. Esimerkiksi muodikas "identiteettipolitiikka" ei rajoitu vain poliittisiksi ymmärrettyihin diskursseihin. Kysymys on myös siitä, miten eri ihmisryhmiä mukaan kutsuvat tai niitä poissulkevat identiteettipoliittiset diskurssit ovat mukana myös taloudellisten, kulttuuristen ja kansallisvaltioiden rajat ylittävien voimasuhteiden artikuloimisessa. Tästä näkökulmasta katsoen onkin ongelmallista pitää identiteettipolitiikkaa populistisine piirteineen "luokkapolitiikan" vastakohtana, sillä ensiksi mainittu liittyy myös yhteiskuntaluokkien ja niiden välisten voimasuhteiden artikuloimiseen. Sen luonteen ymmärtämiseksi on analysoitava kapitalistisen yhteiskuntamuodostuman kulloisiakin kansallisia ja kansainvälisiä erityispiirteitä - ja toisaalta niiden ymmärtäminen edellyttää myös identiteettipolitiikan ottamista mukaan analyysiin. Rajautuminen pelkästään identiteettipoliittiseen näkökulmaan onkin ennemmin kriittisen ymmärryksen rajaaja kuin avaaja.

Millaiseksi uusliberaalien ja uusoikeiston mahdollisesti muodostama liittoutuma tulee kehittymään, riippuu myös siitä, miten vahvoja ja laaja-alaisesti organisoituneita populaareja kansallisia-kansainvälisiä liikkeitä ja liittoutumia tulevina vuosina kehittyy. Epäilemättä nykyinen koronakriisi ja laajemmin ilmastokriisi kapitalismin kriisinä tulee aiheuttamaan poliittisten ja muiden yhteiskunnallisten voimien uudelleen järjestäytymistä ja ehkä myös luomaan edellytyksiä uudenlaisten kansallis-kansainvälisesti populaarien muutosvoimien kehitykselle. Joka tapauksessa globaalin kapitalismin uusi vaihe tulee asettamaan uudenlaisia vaatimuksia myös populismin tutkimukselle. 


\section{POPULISMI JA POLITIIKAN TUTKIMUS}

Populismiin kohdistuva politiikan tutkimus jää pinnalliseksi, mikäli analyysissa rajoitutaan vain "politiikaksi" ymmärrettyyn sektoriin tai poliittisiin puolueisiin tai jopa vain populistisiksi määriteltyihin puolueisiin ja muihin ryhmittymiin. Tämän välttämiseksi on siis tutkittava poliittisia artikulaatioita - artikulaation politiikkoja - yhteyksissään yhteiskuntamuodostumien taloudellisiin ja kulttuurisiin ulottuvuuksiin. Populismin tutkimus, jossa ei tutkita kapitalismia, jää tyhjän päälle. "Taloudellisen" huomioon ottavaa populismin tutkimusta ei tule kuitenkaan ymmärtää kapeasti "taloustieteelliseksi" tutkimukseksi, vaan taloudellisen ulottuvuuden huomioon ottavaksi yhteiskuntateoreettisesti valistuneeksi analyysiksi.

Samalla tapaa "kulttuurisen" huomioon ottavan populismin analyysin ei tule olla vain "kulttuurin" tutkimusta, jossa ei oteta huomioon kulttuuristen käytäntöjen ja ajattelutapojen taloudellisia ja poliittisia ulottuvuuksia tai toisaalta kulttuurisen osallisuutta taloudellisessa ja poliittisessa. Esimerkiksi rasismin ja ksenofobisen nationalismin jokapäiväisten kulttuuristen käytäntöjen ymmärtäminen edellyttää myös niiden poliittisten ja taloudellisten ulottuvuuksien tutkimista. On siis analysoitava "eroavuuksia ykseyden sisällä" eli yhteiskuntamuodostuman eri osatekijöiden keskinäisyhteyksiä kadottamatta kuitenkaan näkyvistä näiden tekijöiden erityispiirteitä tai tulkitsematta niitä vain jonkin yhden ja ainoan lainalaisuuden ilmauksiksi. ${ }^{2}$ Tietenkin yksittäisessä tutkimuksessa tutkimusongelma ja tutkimuksen kohde tulee pystyä rajaamaan, mutta välttämättömistä rajauksista huolimatta populismin kapeasti tulkittu poliittinen, kulttuurinen tai taloudellinen analyysi ei riitä, vaan päinvastoin voi estää laaja-alaisen ja syvälle käyvän ymmärryksen kehittymistä.

Yliopistojen uusliberalisoiminen on kiihdyttänyt tutkimuksen yhä pidemmälle etenevää erikoistumista. Jatkuva kova kilpailu vakansseista ja rahoituksesta on omiaan suosimaan pitkälle erikoistunutta tutkimusta, sillä onhan sellaisen tekeminen keskimäärin nopeammin mitattavia tuloksia tuottavaa kuin tieteenalarajat ylittämään pyrkivä laaja-alainen tutkimustyö. Sellaista voi toki pyrkiä edistämään tieteenalarajat ylittävän poikkitieteellisen tai monitieteisen tutkimushankkeen puitteissa. Tutkijoiden välisen hedelmällisen yhteistyön esteeksi voi kuitenkin muodostua se, että hankkeen työnjako ja toteutus perustuvat jäykkiin tieteenalalähtöisiin identiteetteihin, eikä yhdessä jaettuun pyrkimykseen ylittää pitkälti hallinnollis-taloudellisiin institutionaalisiin järjestelyihin perustuvia tieteenalojen rajoja. Toisin sanoen uusliberalisoitu yliopisto on itsessään monipuolisen ja syvälle käyvän yhteiskuntakriittisen tutkimuksen este. Sitä on omiaan korottamaan pitkin maailmaa varsinkin moniin ihmistieteisiin kohdistetut säästö- ja leikkaustoimet. Populismiin suuntautunut politiikan tutkimus ei voikaan jättää kriittisen tarkastelun ulkopuolelle omaa toimintaympäristöään eli yliopistoa. Nyt sen portteja kolkuttelevat myös uusoikeiston populistit.

MIKKO LAHTINEN

Tässä lehdessä julkaistaan kaksi Ernesto Laclaun ja Chantal Mouffen populismin teoriaa käsittelevää vertaisarvioitua artikkelia. Näistä ensimmäisessä, emeritusprofessori Erkki Vainikkalan 
artikkelissa, tarkastellaan populismin ideologista väkevöitymistä populistisen radikaalioikeiston herättämänä kysymyksenä. Ernesto Laclaun käsittein heikoksi luonnehditun populistisen retoriikan voima, joka nojaa "tyhjien" ja "kelluvien" merkitsijöiden voimaan, voi väkevöityä uudenlaisten linkitysten kautta. Tätä dynamiikkaa avataan Slavoj Žižekin ideologisen fantasian kautta, joka ylittää populismin ristiriidat ja ruokkii populistisen kahtiajaon voimaa. Poliittisten vaatimusten ja täyteyskuvitelmien estyminen tuottaa helposti negatiivisten tyhjien merkitsijöiden paikkoja, sijaisuhreja eli syntipukkeja. Edellä kuvatulla käsitteistöllä tarkastellaan yhtä Jussi Halla-ahon varhaista blogikirjoitusta populistista me-muut-jakoa hyödyntävänä kulttuuri-ideologisena tekstinä, jossa nativistinen fantasia antaa ideologisen ponnen muodoltaan rationaaliselle diskurssille.

Lehden toisessa, laclaulaista populismiteoriaa käsittelevässä artikkelissa Emilia Palonen esittää avartavan näkökulman politiikan ja populismin tutkimiseen merkityskamppailuna. Palosen kehittämän retorisperformatiivisen diskurssiteorian ja soinilaisen perussuomalaisuuden analyysin avulla on mahdollista nähdä, kuinka populismi on erityinen merkityksenannon logiikka tai muoto, joka tuottaa tunteikasta vastakkainasettelua ja "meitä". Populismiin liittyviä hegemoniakamppailuja, vallalla olevien jakolinjojen haastamista ja uudelleen määrittelyä tulisi Palosen mielestä lähestyä merkityksenannon muotona. Etenkin uudet jakolinjat luovat populistisia mahdollisuuksia. Artikkeli tarkastelee soinilaista populismia ja sen nousun logiikkaa sekä tulkitsee ristiriitaisiakin ilmiöitä soinilais-perussuomalaisessa retoriikassa. Artikkelin merkittävänä teoreettisena antina esitellään populismin tutkimukselle hyödylliset peruskäsitteet.

Tämän lehden kolmas vertaisarvioitu artikkeli on Juha Ylisalon tutkimus paikallistason poliittisen kilpailun yhteydestä kuntien talouteen. Koska kunnat ovat suomalaisen hyvinvointivaltiomallin keskiössä, se, miten kunnat hoitavat talouttaan, vaikuttaa koko järjestelmän kestävyyteen. Kunta on monen kansalaisen lähin kosketuspinta julkiseen valtaan ja julkisen talouden hallintaan. Koska kuntien taloustilanne vaihtelee, kuntien talousongelmat ovat jatkuvasti politiikan asialistalla. Artikkeli mittaa missä määrin paikallisen poliittisen järjestelmän kilpailullisuuteen liittyvät muuttujat ovat yhteydessä keskeisiin julkistaloudellisiin muuttujiin, jotka mittaavat kuntien menojen tasoa ja tulorahoituksen riittävyyttä menojen kattamiseen. MannerSuomen kunnat vuosina 2001-2014 kattavan aineiston analyysi viittaa siihen, että menojen tason yhteys puoluejärjestelmän hajanaisuuteen on U:n muotoinen: liian vähäinen ja liian tiukka paikallispoliittinen kamppailu vähentää julkisten varojen tehokasta ja pitkänäköistä käyttöä.

Numerossa 2/2020 julkaistaan myös kolme keskustelua-artikkelia. Näistä kaksi ensimmäistä liittyvät tiukasti toisiinsa, syventäen numeron antia populismin tutkimukseen. Emilia Palonen tarjoaa erillisen käännössaatteen hänen ja Jouni Tillin kääntämään, tässä numerossa julkaistavaan Ernesto Laclaun keskeiseen artikkeliin "Universalism, Particularism and the Question of Identity" (1992). Käännösartikkeli "Universalismi, partikularismi ja kysymys identiteetistä" tekee merkittävän kontribuution suomenkielisen populismitutkimuksen kentälle tarjoamalla käännöksiä keskeisille laclaulaisille termeille.

Numeron kolmas keskustelua-artikkeli on emeritusprofessori Kari Palosen kynästä. Artikkelissaan Palonen käsittelee Max Weberin suhdetta Euroopan unioniin. Palonen tarkoituksella 
provosoi ihmetystä, sillä espanjantautiin vuonna 1920 kuolleella Max Weberillä ei voinut olla mitään käsitystä Euroopan unionista, etenkään sellaisena kuin me sen tunnemme. Palonen lähestyykin Euroopan Unionia Weberin ajatusten kautta, joissa esimerkiksi ymmärretään toteutuneita mahdollisuuksia vertaamalla niitä toteutumattomiin. Palonen ei myöskään ole ainoa Weber-tutkija, joka on pohtinut Weberin suhdetta Euroopan integraatioon. Artikkeli on revisioitu versio Jyväskylän yliopiston politiikan opiskelijain ainejärjestötapaamisessa 5.10.2019 pidetystä esityksestä.

Numeron monipuolisuuteen tuovat oman lisänsä kaksi kirja-arviota. Rauli Mickelsson täydentää numerossa 2/2020 vahvasti esillä olevaa populismi-teemaa arvioimalla sekä Juha Herkmanin viime vuonna julkaistun teoksen Populismin aika (2019: Vastapaino) että Timo Soinin tammikuussa julkaistun ohuemman ytimekkäästi nimetyn teoksen Populismi (2020: Polemia). Mickelsson toteaa arviossaan, että siinä missä Herkmanin teos avaa populismin tutkimuksen niin ansiokkaasti, että sitä voisi suositella populismin oppikirjaksi, Soinin teos jää etenkin tutkimukselliselta anniltaan vähäisemmäksi. Monet Soinin sinänsä mielenkiintoiset avaukset jäävät harmillisen ohuiksi, pinnallisiksi, ja Mickelssonin mukaan jopa melko itsekeskeisiksi.

Jussi Systä arvioi puolestaan Paavo Järvensivun teoksen Rajattomasti rahaa niukkuudessa (2016: Like Kustannus Oy). Arviossa huomataan, että Järvensivun kirjassa avataan myös modernia rahateoriaa (MMT), joka muodostaa kirjan taloudellisen lähtökohdan. Tämä onkin välttämätöntä siksi, että ekologisten kriisien vastaisiin toimiin ryhtymisen tyypillisin vasta-argumentti on perinteisen talousteorian mukainen. Systän mukaan teos onnistuu erinomaisesti purkamaan fossiilisten polttoaineiden kasvavaan käyttöön ja jatkuvaan talouskasvuun perustuvan talouden ja kulttuurin keskeisiä ongelmia, mutta tuo myös näiden tilalle uusia tapoja ajatella ja toimia.

\section{VIITTEET}

1. Laclaun teos Politics and Ideology in Marxist Theory (1977) on merkittävä esitys kapitalismin, fasismin ja populismin suhteista. Siinä hän asemoi taitavasti populismin kapitalistisen yhteiskuntamuodostuman historiallisesti sensitiivisen ja erottelukykyisen analyysin yhteyteen. Sen sijaan hänen myöhemmissä teoksissaan luokkasuhteiden ja kapitalistisen yhteiskunnan erityispiirteiden tarkastelu jää huomattavasti pinnallisemmaksi tai peräti kokonaan tekemättä. Politics and Ideology sisältää monia sellaisia populismin ja kapitalismin yhteyksiä koskevia näkökohtia ja oivalluksia, joita voisi soveltaa myös 2000-luvun nykytodellisuuden analyyseissa - ja myös Laclaun omiin myöhempiin esityksiin kohdistuvassa kriittisessä tarkastelussa.

2. Tarkastellessaan kapitalistista tuotantoa, jakaantumista, vaihtoa ja kulutusta, Marx esittää, "että ne kaikki muodostavat kokonaisuuden osat, ovat eroavuuksia ykseyden sisällä" (Marx 1986, 49). Marxin näkemys "eroavuuksista ykseyden sisällä", jota hän luonnehtii Gliederungiksi, ei suinkaan ole "essentialistinen" tai deterministinen. Hän ei määrittele "taloutta" koko yhteiskuntamuodostuman kehitystä määrääväksi "perustaksi”. Hän ei myöskään ymmärrä "kokonaisuutta" ekspressiiviseksi totaliteetiksi, jonka eri osatekijät enemmän tai vähemmän suoraan heijastaisivat (ekspressoisivat) jotakin oletettua taloudellista lainalaisuutta. Tällainen ekspressiivisen totaliteetin ajatus tekisi osatekijöiden välisistä eroista näennäiseroja. 
Sen sijaan Marx tarkastelee yhteiskuntamuodostumaa sen eri osatekijöiden keskinäisten artikulaatioiden valossa. Varsinkin kehittyneet kapitalistiset yhteiskunnat ovat kompleksisia ja monitahoisia kokonaisuuksia. Niiden kohdallinen ymmärtäminen edellyttää kuitenkin myös työn ja pääoman välisen antagonistisen ristiriidan huomioon ottamista, mutta ei koko yhteiskuntamuodostuman kehitystä deterministisesti määräävänä tekijänä, vaan nimenomaan artikuloiduissa yhteyksissään muihin ristiriitoihin ja vaikuttaviin tekijöihin. Artikulaation näkökulma avaa dynaamisen näkymän yhteiskuntaan ja myös sen tuotantosuhteisiin jatkuvaa työstämistä edellyttävänä poliittisten ja kulttuuristen yhteiskunnallisen kamppailujen todellisuutena. Artikulaatioissa onkin aina kysymys artikulaatioiden politiikasta.

Samansuuntainen näkemys yhteiskunnasta sisältyy myös Antonio Gramscin Vankilavihkojen (1975, kirj. 1929-1935) analyyseihin ja kehittelyihin esimerkiksi "kollektiivisen tahdon" organisoimisesta tai poliittisen yhteiskunnan, kansalaisyhteiskunnan ja taloudellisen tuotannon "historialliseksi blokiksi” organisoimisen pyrkimyksistä. Paljon esillä olleessa mutta usein myös kritiikittömästi omaksutussa Gramsci-tulkinnassaan Laclau ja Mouffe (1985) kuitenkin väittävät, että Gramsci (kuten myös itse Marx) olisi "essentialisti", jolle "taloudellinen perusta" on poliittisten kamppailujen eräänlainen transsendentti lähtökohta. He eivät kuitenkaan kokonaan hylkää Gramscin näkemyksiä, vaan pyrkivät puhdistamaan hänen hegemonian konseptionsa siinä näkemästään essentialismista ja muokatakseen siitä mielestään pätevän poliittisen analyysin välineen omien tutkimustensa tarpeisiin. Tässä jälkistrukturalistisiin ja postmoderneihin teorioihin nojaavassa "anti-essentialistisessa" tai "anti-foundationalistisessa" hankkeessaan he kuitenkin typistävät Gramscin näkemykset alkuperäistä huomattavasti kapeammassa mielessä politiikan teoriaksi, jossa "poliittista" ei aseteta - eikä haluta asettaa - yhteyksiinsä "taloudellisen" kanssa, eikä varsinkaan kiinnitetä huomiota jälkimmäisen erityiseen asemaan ja luonteeseen kapitalistisessa yhteiskuntamuodostumassa. Vertailemalla Laclaun ja Mouffen populismitulkintaa Gramscin Vankilavihkoissaan esittämiin näkemyksiin muun muassa hegemoniasta ja "kansallis-populaarista" (nazionale-popolare) voidaan havaita, että heidän tulkintansa perustuu Vankilavihkojen varsin valikoivaan lukemiseen ja osoittautuu myös filologisesti epätarkaksi analyysiksi (ks. Anselmi 2019, 108-111).

\section{LÄHTEET}

Anselmi, Manuel. 2019. "Gramsci nel dibattito sul populismo contemporaneo". Teoksessa Guido Liguori (toim.), Gramsci e il populismo. Milano: Edizioni Unicopli.

Gramsci, Antonio. 1975: Quaderni del carcere. Edizione critica dell'Istituto Gramsci. Toim. Valentino Gerratana. Torino: Giulio Einaudi editore.

Laclau, Ernesto. 1977. Politics and Ideology in Marxist Theory. Lontoo: New Left Books.

Laclau, Ernesto ja Mouffe, Chantal. 1985. Hegemony and Socialist Strategy. Towards a radical democratic politics. Lontoo: Verso.

Marx, Karl. 1986. Vuosien 1857-1858 taloudelliset käsikirjoitukset (Grundrisse), osa 1. Moskova: Kustannusliike Progress. 